\title{
Student Interest in Continuing Study
}

\author{
$1^{\text {st }}$ Muhamat Qahfi \\ Economic Education Department \\ STKIP Muhammadiyah Sampit \\ Sampit, Indonesia \\ m_qahfi@stkipmsampit.ac.id
}

\author{
$2^{\text {nd }}$ Apuanor \\ Economic Education Department \\ STKIP Muhammadiyah Sampit \\ Sampit, Indonesia \\ apuanor@stkipmsampit.ac.id
}

\author{
$3^{\text {rd }}$ Sudarmono \\ Economic Education Department \\ STKIP Muhammadiyah Sampit \\ Sampit, Indonesia \\ sudar@stkipmsampit.ac.id
}

\begin{abstract}
The purpose of this study was to determine the Interest in Continuing Studies in Class IX Students at SMP Negeri 6 Parenggean in the 2019/2020 Academic Year. The population of this study was all students of grade IX in SMP Negeri 6 Parenggean in the academic year 2019/2020. Samples were taken by the Saturated Sample technique of 25 students. Analysis of the data used quantitative descriptive analysis techniques. Based on the results of data analysis, it can be concluded that, in general, students' interest in continuing studies in IX grade students of SMP Negeri 6 Parenggean includes into the medium category, with details belonging to the low category of 6 respondents $(24 \%)$, medium category of 16 respondents $(64 \%)$ and for the high category was 3 respondents $(12 \%)$. This result was strengthened by the percentage based on the gender of the respondents, which included a low category of $24 \%$ consisting of 2 male respondents $(8 \%)$ and 4 female respondents $(16 \%)$, for students belonging to the moderate category amounted to $64 \%$ which consisted of 6 male respondents $(24 \%)$ and 10 female respondents $(40 \%)$. And for the high category of $12 \%$ consisting of 1 male respondent $(4 \%)$ and 2 female respondents $8 \%$. The results of the study it can be concluded that in general the interests of grade IX students of SMP Negeri 6 Parenggean belong to the medium category of 16 respondents or $64 \%$.
\end{abstract}

\section{Keywords - Student Interest, Continuing Study}

\section{INTRODUCTION}

Education is a conscious and planned effort to create an atmosphere of learning and learning process so that students actively develop their potential to have spiritual strength, self-control, personality, noble character, and the skills needed by themselves and the community. One of the government's policy strategies in improving the quality of Indonesia's human resources is through improving the quality of education. In line with the development of the 21 st century, which is known as the era of globalization, professionalism is needed in all fields including the world of education.

In the current era of globalization, the need for reliable and professional Human Resources (HR) is needed. So that improving the quality of human resources needs to be done with a variety of strategies, one of which is through education. Education serves to create good quality human resources. Therefore, education is expected to be the initial capital for living in facing challenges and competition in the global era. Strategies, approaches, or methods are often created by educators themselves based on knowledge, logic, and experience, which is often referred to as the art of educating in the learning process specifically to increase student interest. According to Slameto [1], interest is a feeling of preferability and a sense of interest in a thing or activity, without anyone asking [1].

According to Muhibbin Syah [2], interest means a tendency and high enthusiasm or a great desire for something [2]. Interest is the result of a learning experience. The type of lessons that give birth to interest will determine how long the interest lasts and the satisfaction derived from the interest. To know how interest develops, it is not only necessary to know but also how aspects of interest develop.

Interest is the acceptance of a relationship between oneself and something outside of oneself. The social environment can affect one's interests because someone lives somewhere there will be communication and in the end, there will be a process of mutual influence between members of the community. Social environmental factors consist of family factors, school friends and community factors into consideration students in making decisions to make choices to the next level of education. According to Anifa Sri Lestari [3], several other considerations such as the future picture that students aspire to will be a factor that influences students' interest in continuing school [3].

Based on the author's observations at the place to be studied, students' interest in continuing their studies was still low, this was supported by data from the District Coordinator of Education Department of Parenggean statement that students who continue their studies to High Schools were only range from 70 to $75 \%$ of junior high school graduates, meaning that there were still around 25\% percent of junior high school graduates who do not continue their studies for various reasons

This study aims to determine the interest in continuing the study of students of SMP Negeri 6 Parenggean in the academic year 2019/2020, and the research is expected to be beneficial for schools to always motivate their students so that there will be an increase in student interest and maturity in making decisions to continue schooling according to their abilities.

Interest has an important role in one's life and has a large impact on behavior and attitudes. According to Slameto [1], interest is a feeling of preferability and a sense of interest in a thing or activity without anyone asking [1]. According to Muhibbin Syah [2], interest means a tendency and high enthusiasm or a great desire for something [2]. According to Saiful Bahri Djamarah [4] interest is a persistent tendency to pay attention and remember some activities. The interest referred to this research is the interest in continuing studies [4]. According to Cicih Purwanti [5] interest in continuing studies is a situation where a person pays attention and has 
interest in education and is accompanied by a desire to know, have, learn and prove by choosing one of this education and carry out all the activities in it [5].

Interest is influenced by several factors; a person's interest is not brought from birth but develops through several stages along with one's development. According to Cicih Purwanti [5] factors that influence interest are divided into two, namely: First; factors from within an individual such as weight, age, gender, experience, feeling of being able, and personality, and Second; factors originating from outside the individual include the family environment, school environment, and community environment [5].

According to Hurlock in Cicih Purwanti [5], interest has two aspects, namely cognitive aspects related to intellectual or knowledge and affective aspects which include attitudes or behaviors [5]. Both aspects of interest can be explained as follows: First; Specific awareness to like activities (specific concussed for or living the activity), which is the state of deciding to like something that creates a sense of interest so that it raises interest in a particular activity or motorcycle taxi without coercion. Second; Activities or certain objects that generate a sense of interest that generate interest so that they have the desire to know, own, and learn firsthand. Third; Curiosity about the activities carried out regarding satisfaction and profit from their interests. This means that attitudes that encourage someone to create curiosity to do something without coercion from within or outside him to cause interest in a particular thing or object. Forth; The general attitude towards activities (general attitude toward the activity), i.e. feelings of like or dislike, agree or disagree with an activity, generally being positive and deciding to like an activity or a particular object. Fifth; Feeling happy with the activity (enjoyment of the activity), i.e. individuals feel happy to do everything related to the activity of their interest. Sixth; The activity has meaning or importance for individuals (personal import or significance of the activity to the individual). This means that individuals feel that an activity that they do is very meaningful. And Seventh; Participating in activities (reported choice of or participants in the activity) i.e. the individual will choose or participate directly in a certain activity because he likes it.

\section{METHOD}

This research was conducted at State Middle School 6 Parenggean from September to November 2019. The type of research used in this study was a descriptive quantitative research method. According to Syamsudin \& Damayanti [6], this kind of research is research that aims to explain the phenomenon that exists by using numbers to describe the characteristics of individuals or groups [6]. This research is generally used to obtain a picture of reality or test the fabric of an existing or existing reality on the subject.

The population in this study was ninth-grade students, amounting to 25 people. Data collection techniques used were closed questionnaires in the form of statements with a total of 20 items. Before the research instruments were used first, validity and reliability tests were performed. To measure the Validity of the test, the writer used the Corrected item-total correlation. To measure the reliability of the test, the writer used Cronbach alpha. From the results of the validity test, 4 items are declared invalid because the correlation value is below $\mathrm{r}$ critical $(0.3)$ so the number of items used in the study is 16 items, while the results of reliability test obtained an alpha value of 0.884 so that the instrument was declared reliable. The data analysis technique used in this study was a quantitative descriptive analysis using the following category formula:

$$
\begin{array}{ll}
\mathrm{X}<\text { mean }-\mathrm{SD} & =\text { Low } \\
\text { Mean }-\mathrm{SD} \leq \mathrm{X} \leq \text { mean }+\mathrm{SD} & =\text { Medium } \\
\mathrm{X}>\text { mean }+\mathrm{SD} & =\text { High }
\end{array}
$$

\section{RESULT AND DISCUSSION}

Data collection from the variable of interest continues the study with 2 (two) aspects used, namely cognitive and affective aspects to obtain a general description of the research aspects score which includes a minimum score, maximum score and average using a questionnaire method distributed to 25 respondents namely students of SMPN 6 Parenggean in 2019/2020 academic year. Details of data are presented in the following table:

TABLE 1. OVERVIEW OF ASPECTS OF INTEREST IN CONTINUING THE STUDY

\begin{tabular}{|c|r|r|r|r|r|}
\hline & N & $\begin{array}{r}\text { Mini } \\
\text { mum }\end{array}$ & $\begin{array}{c}\text { Maxi } \\
\text { mum }\end{array}$ & Mean & $\begin{array}{c}\text { Std. } \\
\text { Deviation }\end{array}$ \\
\hline $\begin{array}{c}\text { Cognitive } \\
\text { Aspect }\end{array}$ & 25 & 11 & 28 & 17,9 & 4,72 \\
\hline $\begin{array}{c}\text { Affective } \\
\text { Aspect }\end{array}$ & 25 & 12 & 35 & 21,4 & 6,43 \\
\hline $\begin{array}{c}\text { N Valid } \\
\text { (listwise) }\end{array}$ & 25 & & & & \\
\hline
\end{tabular}

From the table above, it can be explained that the aspects of interest in continuing studies are divided into cognitive and affective aspects. There are 7 items of cognitive aspects with a minimum score of 11 , a maximum score of 28 , and a means of 28. While effective aspects there are 9 items with a minimum score of 12 , a maximum score of 35 , and a means of 21.4. Based on the tabulation scores obtained, a general picture of the students' interest in continuing their studies is described in the following table:

TABLE 2. OVERVIEW OF INTEREST IN CONTINUING STUDY

\begin{tabular}{|l|c|c|c|}
\hline \multicolumn{1}{|c|}{ Variable } & Statistics & $\begin{array}{l}\text { Hypothetical } \\
\text { Score }\end{array}$ & $\begin{array}{l}\text { Empirical } \\
\text { Score }\end{array}$ \\
\hline $\begin{array}{l}\text { Interest in } \\
\text { the } \\
\text { Continuing } \\
\text { Study }\end{array}$ & $\begin{array}{c}\text { Minimum } \\
\text { Score }\end{array}$ & 16 & 27 \\
\cline { 2 - 4 } & $\begin{array}{c}\text { Maximum } \\
\text { Score }\end{array}$ & 64 & 62 \\
\cline { 2 - 4 } & Mean & - & 39,32 \\
\cline { 2 - 4 } & $\begin{array}{c}\text { Deviation } \\
\text { Standard }\end{array}$ & - & 10,09 \\
\hline
\end{tabular}

After the data is collected, data analysis is performed using percentage descriptive techniques by categorizing. The purpose of categorization is to place individuals into separate groups in stages according to a continuum based on measured attributes. The number of levels of diagnosis categorization used does not exceed five levels but also not fewer than three levels. The researcher determined three categorizations according to the desired level of differentiation, namely high, medium, and low. 
The categorization is based on the standard deviation unit and the mean on the empirical score, with the following formula:

$$
\begin{array}{ll}
\mathrm{X}<\text { mean }-\mathrm{SD} & =\text { Low } \\
\text { Mean }-\mathrm{SD} \leq \mathrm{X} \leq \text { mean }+\mathrm{SD} & =\text { Medium } \\
\mathrm{X}>\text { mean }+\mathrm{SD} & =\text { High }
\end{array}
$$

From the data analysis, the following results were obtained:

TABLE 3. CRITERIA FOR INTEREST CATEGORY LEVELS

\begin{tabular}{|c|c|c|c|c|}
\hline No. & Range & Respondents & $\begin{array}{c}\text { Percen- } \\
\text { tage }\end{array}$ & $\begin{array}{c}\text { Categ } \\
\text { ory }\end{array}$ \\
\hline 1 & $\mathrm{X}<29,23$ & 6 & $24 \%$ & Low \\
\hline 2 & $\begin{array}{c}29,23 \leq \mathrm{X} \\
\leq 49,41\end{array}$ & 16 & $64 \%$ & Medi \\
um \\
\hline 3 & $\mathrm{X}>49,41$ & 3 & $12 \%$ & High \\
\hline
\end{tabular}

Based on the results of data analysis, it was found that interest in continuing the study of class IX students of SMP Negeri 6 Parenggean was more dominant in the medium category, namely $64 \%$ of the total number of research respondents. This is influenced by many factors as stated Cicih Purwanti (2013: 30) factors that affect interest are divided into two, namely: first; Factors from within an individual such as weight, age, gender, experience, feeling of being able, and personality, and second; Factors originating from outside the individual include the family environment, school environment, and community environment.

Meanwhile, there are still $26 \%$ of some low-interest students at SMP Negeri 6 Parenggean according to the authors based on interviews during pre-research factors that are more dominant affecting the interest in continuing studies there are factors outside the individual including the family environment and community environment. Those who have high interests tend to explore their abilitie s more, have a strong curiosity or interest in something they want and are willing to work hard to realize their desires. To create a feeling of pleasure, a sense of interest, attention and a strong desire for something can be achieved in various ways. One of them can be done by the teacher or the school continually providing motivation and guidance so that students 'motivation to grow after graduating from junior high school will continue their studies, providing support facilities so that students can develop abilities according to what they have to increase students' interest in going to school following their talents and the abilities they have.

\section{CONCLUSION}

Based on the results of the study it can be concluded that in general the interests of grade IX students of SMP Negeri 6 Parenggean belong to the medium category of 16 respondents or $64 \%$.

\section{REFERENCES}

[1] Slameto, Belajar dan Faktor-faktor yang Mempengaruhinya, Jakarta: Rineka Cipta, 2013.

[2] M. Syah, Psikologi Belajar, Jakarta: PT. Raja Grafindo Persada, 2006.

[3] A. S. Lestari, Minat Siswa Melanjutkan Studi Ke Sekolah Menengah
Kejuruan (Smk) Ditinjau Dari Lingkungan Sosial Dan Orientasi Masa Depan Pada Siswa Kelas Ix Smp Negeri 3 Jatisrono Tahun Ajaran 2011-2012, Surakarta: Universitas Muhammadiyah Surakarta, 2012.

[4] S. B. Djamarah, Psikologi Belajar, Jakarta: Rineka Cipta, 2011.

[5] C. Purwanti, Meningkatkan Minat Studi Lanjut Ke Smk Melalui Layanan Informasi Karier Pada Siswa Kelas VIII SMP Negeri 2 Salem (Kabupaten Brebes Tahun Ajaran 2012/2013), Semarang: Universitas Negeri Semarang, 2013.

[6] S. D. Damayanti, Metode Penelitian Pendidikan Bahasa, Bandung: Remaja Rosdakarya, 2011. 